\title{
Workplace Spirituality, Perceived Organizational Support, and Organizational Commitment among Auditors
}

Nasina Mat Desa, Doris Koh Pin Pin, Muhammad Hasmi Abu Hassan Asaari

To Link this Article: http://dx.doi.org/10.6007/IJARBSS/v11-i6/10171

DOI:10.6007/IJARBSS/v11-i6/10171

Received: 06 April 2021, Revised: 26 April 2021, Accepted: 17 May 2021

Published Online: 14 June 2021

In-Text Citation: (Desa et al., 2021)

To Cite this Article: Desa, N. M., Pin, D. K. P., \& Asaari, M. H. A. H. (2021). Workplace Spirituality, Perceived Organizational Support, and Organizational Commitment among Auditors. International Journal of Academic Research in Business and Social Sciences, 11(6), 432-452.

\section{Copyright: @ 2021 The Author(s)}

Published by Human Resource Management Academic Research Society (www.hrmars.com)

This article is published under the Creative Commons Attribution (CC BY 4.0) license. Anyone may reproduce, distribute, translate and create derivative works of this article (for both commercial and non-commercial purposes), subject to full attribution to the original publication and authors. The full terms of this license may be seen at: http://creativecommons.org/licences/by/4.0/legalcode

Vol. 11, No. 6, 2021, Pg. 432 - 452

Full Terms \& Conditions of access and use can be found at http://hrmars.com/index.php/pages/detail/publication-ethics 


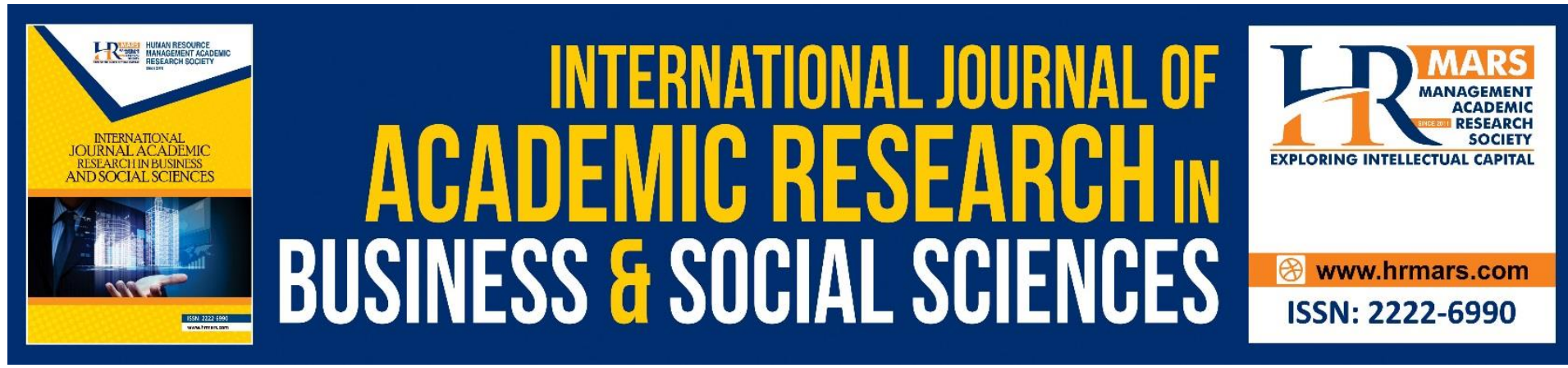

\title{
Workplace Spirituality, Perceived Organizational Support, and Organizational Commitment among Auditors
}

\author{
Nasina Mat Desa \\ Management Section School of Distance Education Universiti Sains Malaysia \\ Email: nasina@usm.my \\ Doris Koh Pin Pin \\ Management Section School of Distance Education Universiti Sains Malaysia \\ Email: doriskpp@gmail.com \\ Muhammad Hasmi Abu Hassan Asaari \\ Management Section School of Distance Education Universiti Sains Malaysia \\ Email: hasmi@usm.my
}

\begin{abstract}
This study focuses on the auditors who are working in the Big Four public accounting firms; the largest international professional services networks in accountancy and professional services, which handle the vast majority of audits for publicly traded companies as well as many private companies, creating an oligopoly in auditing large companies. The recent scenario of all the Malaysian organizations indicates that we are lacking highly committed employees. The organizations have had a common complaint about the fact that their current employees are not as loyal as their employees used to be in the past. The objectives of this study are to explore the relationship and impact between workplace spirituality and organizational commitment with the mediation of perceived organizational support. Selfadministered questionnaires were used in data collection were distributed among auditors in Penang comprised of 400 in the population. A total of 300 questionnaires were distributed with a response rate of $69 \%$. The PLS is employed in the data analysis. The result discovers that workplace spirituality has an impact on organizational commitment, and the perceived organizational support has a partial mediation between them. This study contributes to the existing literature on the relationship and impact between workplace spirituality and organizational commitment with the mediation of perceived organizational support among auditors in the big four accounting firms.
\end{abstract}

Keywords: Workplace Spirituality, Organizational Commitment, Perceived Organizational Support, Auditors, Accounting Firms 


\section{Introduction}

The issues of brain drain among accounting professionals, namely auditors, in Malaysia had been felt by various accounting firms in the country. The syndrome of brain drain had been moving to the countries such as Singapore, China, Hong Kong, United Kingdom, and the Middle East particularly the Gulf Cooperation Council (GCC) nations (Tomlinson, Abdullah, \& Kolesnikov-Jessop, 2008). Moreover, Tomlinson et al (2008) anticipated that by the nation would face a shortage of almost 20,000 qualified accountants. The issue of brain drain among accountants in the nation also addressed through the forum by the Accountant Today (Ravendran, 2008). On the other hand, the level of organizational commitment among auditors in the nation had been influenced by the extrinsic and intrinsic rewards. This was mentioned by Cohen and Gattiker (1994); Oliver (1990) on the literatures pertaining to rewards and organizational commitment. Interestingly, auditors were not motivated with the extrinsic rewards to commit but may be lacking in the intrinsic rewards too, such as workplace spirituality. Mottaz (1988), who asserts that intrinsic rewards such as task autonomy, task significance, and task involvement are the most powerful determinant of organizational commitment among professional, managerial, clerical, service, and blue-collar workers.

The problem that is to be explored in this study is the low level of organizational commitment reflected by these auditors towards their employers. Thus, this study replicates the works of Rego and Cunha (2008) in determining the correlation between workplace spirituality and organizational commitment among auditors in the nation. Moreover, the study also considers the mediation effect of perceived organizational support. The objectives of this study is:

1. To investigate the relationship between workplace spirituality and organizational commitment with the mediation of perceived organizational support among auditors.

2. To anticipates the impact of workplace spirituality and organizational commitment with the mediation of perceived organizational support among auditors.

\section{Literature Review \\ Workplace Spirituality}

Giacalone and Jukiewicz (2003) defined workplace spirituality as a framework of organizational values evidenced in the culture that promotes employees' experience of transcendence through the work process, facilitating their sense of being connected to others in a way that provides feelings of completeness and joy. The workplace spirituality comprises five dimensions from the works of Rego and Cunha (2008). Firstly, the team's sense of community that refers to the team spirit, interactions between employees and their coworkers, including support, genuine caring and freedom of expression among the team members, sense of community, and sense of common purpose. Secondly, alignment between organizational and individual values refers to employees who experience a strong sense of the bond between their inner lives and their organization's mission and purposes. Thirdly, a sense of contribution to the community that refers to employees having a deep sense of meaning and purpose in their work and in harmony with their life ideal values and contributing to the community. Fourthly, a sense of enjoyment at work refers to another way to attain meaning at work. Finally, opportunities for inner life concerns with the conditions of spirituality. 
Meanwhile, Ashmos and Dunchon (2000) defined that workplace spirituality is about employees who understand themselves as spiritual beings whose souls need nourishment at work and about experiencing a sense of purpose and meaning in their work, and experiencing a sense of connectedness to one another and their workplace community. Lloyd (1990) discovered that an organization with highly influenced workplace spirituality can outperform other organizations with either little or no workplace spirituality. Thompson (2000) found that the more spirited companies tend to have outperformed the others. Furthermore, Turner (1999) has highlighted that workplace spirituality has a huge impact on an organization since the organization can gain advantages by developing a humanistic environment in which workers can achieve their full potential.

\section{Organizational Commitment}

Allen and Meyer (1996) defined organizational commitment as a psychological link between the employees and the organization that makes it less likely that the employee will voluntarily leave the organization. They stated that organizational commitment comprised of affective commitment, normative commitment, and continuance commitment. Firstly, affective commitment refers to the identification with, involvement in an emotional attachment to, the organization. Employees with strong affective commitment remain in the organization because they want to do so. Secondly, the continuance commitment refers to the employees' recognition of the costs associated with them leaving the organization. Employees with a strong continuance commitment will remain in an organization because they have to do so. Finally, the normative commitment refers to a sense of obligation to the organization. Employees with a high normative commitment will remain in the organization because they ought to do so.

Interestingly, the low levels of organizational commitment could lead to higher turnover (Porter, Steers, Mowday \& Boulian, 1974; Mowday et al., 1982; Aranya, Kushnir, \& Valency, 1986; Aryee, Wyatt, \& Ma, 1991; Bennett \& Durkin, 2000), absenteeism (Steers, 1977; Koch \& Steers, 1978; Bennett \& Durkin, 2000), poor job performance (Meyer \& Allen, 1997; Iverson \& Buttigieg, 1999; Clugston, 2000; Jaramillo, Mulki \& Marshall, 2005; Park \& Rainey, 2007), turnover intention, actual turnover, poor organizational citizenship behaviors, and it also affects the employee's health and well-being (Meyer, Stanley, Herscovitch, \& Topolnytsky, 2002). Hence, Tayyab (2006) stated that considering the costs associated with turnover, it is potentially important by finding ways to increase employees' commitment.

\section{Perceived Organizational Support}

Eisenberger, Huntington, Hutchinson, and Sowa (1986) defined perceived organizational support as the extent to which the organization values their contributions and cares about their well-being. Meanwhile, Rhoades and Eisenberger (2002) viewed perceived organizational support as the extent to which an organization rewards work efforts, meets the emotional needs of employees, is perceived to respond to the worker's values and needs. This suggested as employees feel the organization cares about their well-being, then they felt the obligation to help the organization reach its objective. Moreover, perceived organizational support did strengthen the employees' belief that the organization acknowledges and rewards superior performance to them as such improve employees' organizational commitment, job-related effect, job involvement, performance, strains, intention to leave, and withdrawal behavior (Shore \& Shore, 1995; Rhoades \& Eisenberger, 
2002). Therefore, the feeling of employees on the treatment as favorable and unfavorable by the organization had an impact on their contributions and cares to the organization.

On the other hand, Nasurdin, Hemdi, and Lye (2008) found that perceived organizational support mediate the relationship between human resource management practices, namely career development and performance appraisal, toward organizational commitment. Allen, Shore, and Griffeth (2003) also reported that perceived organizational support mediated the relationship between commitment and decision making, job security, and fairness of rewards. Rhoades et al. (2001) found that perceived organizational support influenced the relationship between commitment and organizational rewards, procedural justice, and supervisor support. Research has shown that procedural justice perceptions affected work outcomes such as commitment, satisfaction, and intent to quit via the influence of perceived organizational support (Masterson, Lewis, Goldman, \& Taylor, 2000). Thus, these posits that perceived organizational support could be considered as a mediator in this study.

\section{The Relationship between Workplace Spirituality and Organizational Commitment}

Marques, Dhiman, and King (2007) indicated that when an organization consciously attempts to nurture spirituality in the workplace, the entire people within the organization will be more attuned to a spiritual mindset. Subsequently, workplace spirituality was instrumental in enhancing employees' organizational commitment (Krishnakumar \& Neck, 2002; Moore \& Casper, 2006; Rego \& Cunha, 2008). Eisenberger et al. (1986) stated that employees who perceived that their organization attempts to nurture spirituality in the workplace will experience greater perceived organizational support and increase the organizational commitment. Meanwhile, Allen et al. (2003) discovered that the employees were less likely to leave the organization. Therefore, workplace spirituality would significantly and positively influence their affective, normative commitment, and continuance commitment to the organization. Thus, the study posits the hypothesis that:

$\mathrm{H}_{1}$ : Workplace spirituality has a positive impact on organizational commitment among auditors.

\section{The Relationship between Workplace Spirituality and Perceived Organizational Support}

Rhoades and Eisenberger (2002) suggested there were three main antecedents of perceived organizational support such as fair organizational procedures, supervisors' support, and favorable rewards and job conditions. Most of the organizational support antecedents are largely based on the different forms of organizational favorable treatment. Among them is the form of intrinsic rewards such as workplace spirituality. The employee perception of workplace spirituality would have an impact on perceived organizational support. Thus, this study posits the hypothesis that:

$\mathrm{H}_{2}$ : Workplace spirituality has a positive impact on perceived organizational support among auditors.

\section{The Relationship between Perceived Organizational Support and Organizational Commitment}

Various studies claimed that perceived organizational support creates a feeling of obligation to support the organization, and the employees who feel they are supported by the 
organization will reciprocate with higher organizational commitment (Eisenberger et al., 1986, 1990, 2001; Hutchison, 1997; Rhoades \& Eisenberger, 2002). Rhoades and Eisenberger (2002) found several consequences of organizational support, such as organizational commitment, job-related effect, job involvement, retention, performance, strains, and job satisfaction. Hence, employees perceived organizational support would directly and positively influence their affective and normative commitment. Thus, this study posits the hypothesis that:

$\mathrm{H}_{3}$ : Perceived organizational support has a positive impact on organizational commitment among auditors.

The Relationship between Workplace Spirituality, Perceived Organizational Support, and Organizational Commitment

Strategic human resources management perspective claimed that organization has chosen to invest in its human capital to sustain competitive advantage through spiritual work and employees. By further examining the impact of workplace spirituality on employee's organizational commitment and perceived organizational support as the mechanism through which this occurs, this contributed towards potentially addressing the black box in the human resource management literature. Thus, this study posits the hypothesis that:

$\mathrm{H}_{4}$ : Workplace spirituality has a positive impact on organizational commitment with the mediation of perceived organizational support among auditors.

\section{Theoretical Framework}

Drawing from Social Exchange Theory (Blau, 1964), this study conceptualized workplace spirituality and organizational commitment; namely the affective commitment, normative commitment, and continuance commitment, with the mediation of perceived organizational support among auditors in the accounting firms as depicted in Figure 1.

Figure 1: Theoretical Framework

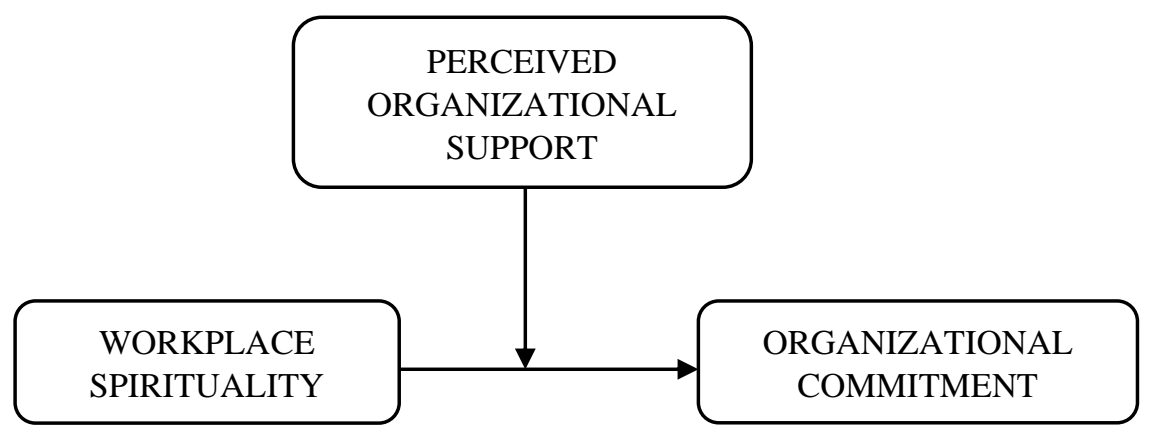

\section{Methodology}

The study's population and sample were the auditors in the accounting forms in the Northern Region of the nation. The auditors would be sought from the list of the Big Four accounting forms in the region, namely KPMG, Deloitte Touche Tohmatsu, Ernst \& Young, and PricewaterhouseCoopers (Suddaby, Gendron \& Lam, 2009). The respondents were be obtained through a simple random sampling method. 
A self-administered questionnaires were distributed among the auditors in the Big Four accounting firms. The questionnaires were emailed to the human resource representative of each firm. All the questionnaire instruments were adopted from various published literature besides the demographic factors. The questionnaire comprised of four sections: Section $A$ comprised of demographic questions, Section B comprised of the workplace spirituality questions, Section $C$ comprised of perceived organizational support questions, and Section $D$ comprised of organizational commitment questions. Table 1 depicts the reliability of the questions used.

Table 1: Research Tools

\begin{tabular}{|l|l|c|c|}
\hline \multicolumn{1}{|c|}{ Item \& Source } & \multicolumn{1}{|c|}{ Source } & $\mathrm{n}$ & $\alpha$ \\
\hline Workplace Spirituality & $\begin{array}{l}\text { Rego and Cunha } \\
(2008)\end{array}$ & 17 & $0.67-0.88$ \\
\hline $\begin{array}{l}\text { Organizational } \\
\text { Commitment }\end{array}$ & Meyer et al. (1993) & 18 & $0.78-0.91$ \\
\hline $\begin{array}{l}\text { Perceived Organizational } \\
\text { Support }\end{array}$ & $\begin{array}{l}\text { Eisenberger et al. } \\
(1990)\end{array}$ & 9 & 0.97 \\
\hline
\end{tabular}

\section{Data Analysis}

Table 4.1 depicts the response rate for each firm in this study. Three-hundred questionnaires were distributed among auditors in the Big Four accounting firms. A total of 207 useable questionnaires were collected with are return rated of $69 \%$.

Table 2: The Big Four Firms and Overall Response Rates

\begin{tabular}{|c|c|c|c|c|}
\hline Firm & $\mathrm{n}$ & Distributed & Collected & $\%$ \\
\hline Firm A & 80 & 60 & 34 & 56.7 \\
\hline Firm B & 95 & 72 & 46 & 63.9 \\
\hline Firm C & 120 & 90 & 59 & 65.6 \\
\hline Firm D & 105 & 78 & 68 & 87.2 \\
\hline Total & 400 & 300 & 207 & 69.0 \\
\hline
\end{tabular}

Table 3 depicts the demographic analysis. Majority of the respondents in this study were female $(n=115 ; 55.6 \%)$ as compared to male $(n=92 ; 44.4 \%)$. Most respondents were single $(n=183 ; 88.4 \%)$ as compared to married $(n=24 ; 11.6 \%)$. The majority of them are relatively young. Most come from the age below 30 years old ( $n=201 ; 97.1 \%)$; meanwhile, the age between 31 to 40 years old were $6(2.9 \%)$. Academically, the majority of respondents were degree holders ( $n=129 ; 62.3 \%)$. There are 71 respondents (34.3\%) who had the Association of Chartered Certified Accountants (ACCA) qualification and only a minority had Certified Public Accountants (CPA) qualification ( $n=7 ; 3.4 \%)$. Both the ACCA and CPA qualifications are recognized around the world. The $3.4 \%(n=7)$ of the respondents were graduated with a CPA from Australia while the $34.3 \%(n=71)$ respondents who graduated from the ACCA examination had undergone an accounting program from London. Concerning the position, out of the 207 respondents, the majority of the respondents were the associate's level auditor ( $n=126 ; 60.9 \%)$. Besides, there were $30.9 \%(n=64)$ of the respondents have achieved the status of the senior level and only $8.2 \%(n=17)$ were from the managerial level.

In the organizational tenure, $45.9 \%(n=95)$ of the respondents have 12 to 24 months of experiences followed by $30.9 \%(n=64)$ of the respondents who have 25 to 36 months of 
experiences, and $12.6 \%(n=26)$ of the respondents have 37 to 48 months of experiences. The minorities of $2.4 \%(n=5)$ of the respondents have 49 to 60 months of experience in that firm, and the remaining $8.2 \%(n=17)$ of respondents indicated that they have worked at the current firms for more than 60 months. On the position tenure, $28.0 \%(n=58)$ of the respondents have been in their current positions for 1 to 12 months. Most of the respondents are at their positions within the 13 to 24 month period ( $n=126 ; 60.9 \%)$. A total of $6.3 \%(n=13)$ of the respondents have been at their position within 25 to 36 months, while the rest of $4.8 \%(n=10)$ claimed to have worked at the current position for more than 36 months.

Table 3: Demographic Analysis

\begin{tabular}{|l|l|r|r|}
\hline \multicolumn{1}{|c|}{ Item } & \multicolumn{1}{|c|}{ Categories } & \multicolumn{1}{c|}{$\mathrm{n}$} & \multicolumn{1}{c|}{$\%$} \\
\hline Gender & Male & 92 & 44.4 \\
& Female & 115 & 55.6 \\
\hline Marital Status & Single & 183 & 88.4 \\
& Married & 24 & 11.6 \\
\hline Age & Less than 20 years & 8 & 3.9 \\
& 21 to 30 years & 193 & 93.2 \\
& 31 to 40 years & 6 & 2.9 \\
\hline Qualification & Degree Holder & 129 & 62.3 \\
& ACCA & 71 & 34.3 \\
& CPA & 7 & 3.4 \\
\hline Position Level & Associate & 126 & 60.9 \\
& Senior & 64 & 30.9 \\
& Manager & 17 & 8.2 \\
\hline Organization Tenure & $12-24$ & 95 & 45.9 \\
(months) & $25-36$ & 64 & 30.9 \\
& $37-48$ & 26 & 12.6 \\
& $49-60$ & 5 & 2.4 \\
& $>60$ & 17 & 8.2 \\
\hline Position Tenure & $1-12$ & 58 & 28.0 \\
(months) & $13-24$ & 126 & 60.9 \\
& $25-36$ & 13 & 6.3 \\
& $>36$ & 10 & 4.8 \\
\hline
\end{tabular}

\section{Reliability Analysis}

Table 4 depicts the reliability analysis of the measures was conducted by using Cronbach's alpha coefficient and composite reliability. The reliability of a measure indicates the stability and consistency of the instrument in measuring a concept and helps to assess the goodness of a measure (Sekaran, 2003).

Table 4: Reliability Analysis

\begin{tabular}{|l|c|c|}
\hline \multicolumn{1}{|c|}{ Item \& Source } & $\mathrm{n}$ & $\alpha$ \\
\hline Workplace Spirituality & 16 & $0.57-0.83$ \\
\hline Organizational Commitment & 5 & 0.77 \\
\hline Perceived Organizational Support & 13 & $0.76-0.87$ \\
\hline
\end{tabular}




\section{Hypotheses Analysis}

The PLS structural model was used in examining the path coefficients $(\beta)$ to test the hypotheses generated. The path coefficients generated by PLS indicate the relationships and can be used similarly to the traditional regression coefficients (Gefen, Straub \& Boudreau, 2000). The $t$-values of each coefficient were obtained by applying a bootstrap procedure (Efron \& Tibshirani, 1993; Bakshi \& Krishna, 2009; Chin, 2010). The t-values of the parameter indicate the strength of the relationship the parameter represents; therefore the higher the $t$-value, the stronger the relationship is (Huang, Lin, \& Chuang, 2007). The $\mathrm{R}^{2}$ values of the endogenous (dependent) constructs indicate whether a particular PLS model accomplishes the objective of maximizing the variance explained (Hulland, 1999; Schepers, Wetzels \& Ruyter, 2005).

\section{The Relationship between Workplace Spirituality and Organizational Commitment}

A model without the mediation effect was utilized to examine the relationship between workplace spirituality and organizational commitment. Figure 2 and Table 5 showed the results of Hypotheses 1 . The $R^{2}$ value of 0.561 suggests that $56.1 \%$ of the variance in the extent of affective commitment can be explained by the five dimensions of workplace spirituality. This study has found that affective commitment was the highest among the three dependent variables. On the other hand, the $\mathrm{R}^{2}$ value of 0.485 suggests that $48.5 \%$ of the variance in the extent of normative commitment can be explained by the five dimensions of workplace spirituality. Continuance commitment was the lowest, with the $\mathrm{R}^{2}$ value was only 0.266 suggesting $26.6 \%$ can be explained by the five dimensions of workplace spirituality.

From Table 5, there was one out of five dimensions of workplace spirituality that was not a significant predictor of affective commitment. Alignment with organizational values $(\beta=0.196$, $p<0.01)$, sense of contribution to the community $(\beta=0.170, p<0.01)$, enjoyment at work $(\beta=0.294, p<0.01)$, and opportunity for inner life $(\beta=0.309, p<0.01)$ were positively related to affective commitment, whereas team's sense of community was not a significant predictor of affective commitment. The hypothesis $\mathrm{H}_{1 \mathrm{a}}$ was not supported, whereas $\mathrm{H}_{1 \mathrm{~b}}, \mathrm{H}_{1 c}, \mathrm{H}_{1 \mathrm{~d}}$, and $\mathrm{H}_{1 \mathrm{e}}$ were supported. Besides, a closer look at Table 5 shows that two out of five dimensions of workplace spirituality were not significant predictors of normative commitment. Alignment with organizational values $(\beta=0.372, p<0.01)$, enjoyment at work $(\beta=0.287, p<0.01)$, and opportunity for inner life $(\beta=0.238, p<0.01)$ were positively related to normative commitment, whereas team's sense of community and sense of contribution to the community were not significant predictors of affective commitment. Therefore, hypotheses $\mathrm{H}_{1 \mathrm{f}}$ and $\mathrm{H}_{1 \mathrm{~h}}$ were not supported, whereas $\mathrm{H}_{1 \mathrm{~g}}, \mathrm{H}_{1 \mathrm{i}}$, and $\mathrm{H}_{1 \mathrm{j}}$ were supported. From the perspective of continuance commitment, two dimensions were negatively predicting the continuance commitment which was the team's sense of community $(\beta=-0.275, p<0.01)$ and enjoyment at work $(\beta=-0.425, p<0.01)$. This study developed the hypothesis between the relation of workplace spirituality and continuance commitment was negative. The hypotheses of $\mathrm{H}_{1 \mathrm{k}}$ and $\mathrm{H}_{1 \mathrm{n}}$ were supported. On the other hand, alignment with organizational values, sense of contribution to the community, and opportunity for inner life were not significant predictors of continuance commitment. The hypotheses of $\mathrm{H}_{1 l}, \mathrm{H}_{1 \mathrm{~m}}$, and $\mathrm{H}_{10}$ were not supported. Thus, overall the hypothesis $\mathrm{H}_{1}$ is partially supported. 
Figure 2: Results of the Path Analysis (Without Mediator)

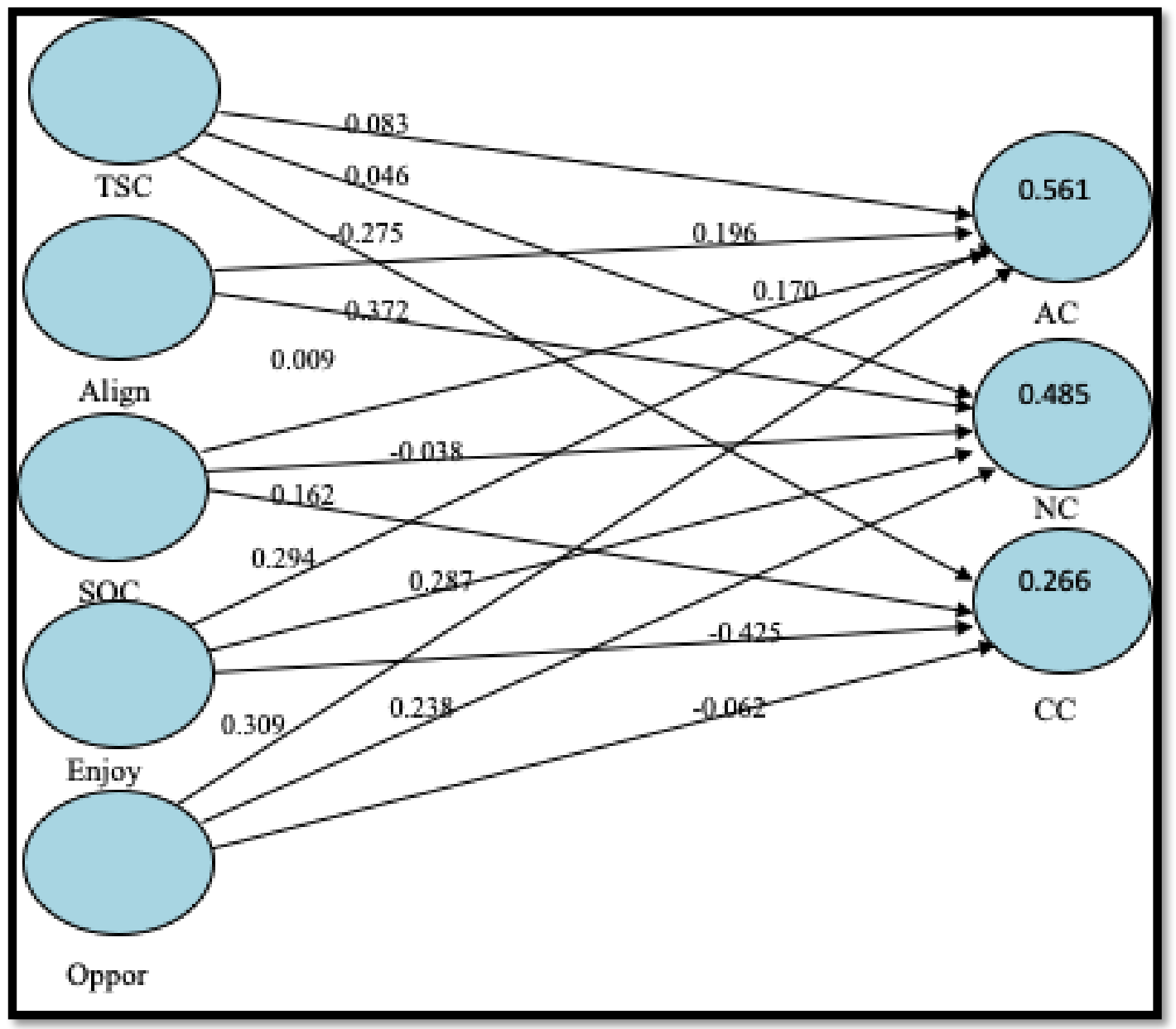

Table 5: Path Coefficients and Hypotheses Testing (Without Mediator)

\begin{tabular}{lllcc}
\hline Hypothesis & \multicolumn{1}{c}{ Relationship } & Path Coefficient & $t$-value & Supported \\
\hline $\mathrm{H} 1 \mathrm{a}$ & TSC $\rightarrow \mathrm{AC}$ & 0.083 & 1.284 & NO \\
$\mathrm{H} 1 \mathrm{~b}$ & Align $\rightarrow \mathrm{AC}$ & $0.196^{* * *}$ & 2.921 & YES \\
$\mathrm{H} 1 \mathrm{c}$ & $\mathrm{SOC} \rightarrow \mathrm{AC}$ & $0.170^{* * *}$ & 2.719 & YES \\
$\mathrm{H} 1 \mathrm{~d}$ & Enjoy $\rightarrow \mathrm{AC}$ & $0.294^{* * *}$ & 5.578 & YES \\
$\mathrm{H} 1 \mathrm{e}$ & Oppor $\rightarrow \mathrm{AC}$ & $0.309^{* * *}$ & 5.542 & YES \\
$\mathrm{H} 1 \mathrm{f}$ & TSC $\rightarrow \mathrm{NC}$ & 0.046 & 0.726 & NO \\
$\mathrm{H} 1 \mathrm{~g}$ & Align $\rightarrow \mathrm{NC}$ & $0.372^{* * *}$ & 5.374 & YES \\
$\mathrm{H} 1 \mathrm{~h}$ & $\mathrm{SOC} \rightarrow \mathrm{NC}$ & -0.038 & 0.569 & NO \\
$\mathrm{H} 1 \mathrm{i}$ & Enjoy $\rightarrow \mathrm{NC}$ & $0.287^{* * *}$ & 4.110 & YES \\
$\mathrm{H} 1 \mathrm{j}$ & Oppor $\rightarrow \mathrm{NC}$ & $0.238^{* * *}$ & 3.492 & YES \\
$\mathrm{H} 1 \mathrm{k}$ & TSC $\rightarrow \mathrm{CC}$ & $-0.275^{* * *}$ & 3.446 & YES \\
$\mathrm{H} 1 \mathrm{l}$ & Align $\rightarrow \mathrm{CC}$ & 0.009 & 0.120 & NO \\
$\mathrm{H} 1 \mathrm{~m}$ & SOC $\rightarrow \mathrm{CC}$ & 0.162 & 1.740 & NO \\
$\mathrm{H} 1 \mathrm{n}$ & Enjoy $\rightarrow \mathrm{CC}$ & $-0.425^{* * *}$ & 6.822 & YES \\
$\mathrm{H} 1 \mathrm{o}$ & Oppor $\rightarrow \mathrm{CC}$ & -0.062 & 0.676 & NO \\
\hline$* * * p<.01$ at $t$-value $=2.58, * * p .05$ at $t$-value $=1.96$ & &
\end{tabular}


Employees with strong affective commitment have involvement in and strong emotional attachment to the organization due to the acceptance of the organizational values (Porter et al., 1974; Meyer \& Allen, 1984; Shore \& Shore, 1995). When employees have a strong emotional attachment to the organization, they will enjoy the memberships in the organization and have an infinite desire to remain with the organization (Porter et al., 1974). The study revealed that workplace spirituality was significantly and positively related to affective commitment, which is consistent with the findings of Rego and Cunha (2008). This study found that four dimensions of workplace spirituality were positively and significantly related to affective commitment. In detail, the opportunity for inner life was found to be the strongest predictor of auditors' affective commitment, followed by enjoyment at work, alignment between organizational and individual values, and a sense of contribution to the community. However, there was one dimension of workplace spirituality that was not a significant predictor of affective commitment, the team's sense of community. The findings implied that employees who perceived high opportunity for inner life would perceive higher affective commitment. Similarly, employees who felt that they experience enjoyment at their work, who felt that the organizational values are aligned with their values, and who sense the organization have a contribution to the community, would contribute to higher affective commitment.

This study found that there were three dimensions of workplace spirituality that were positively and significantly related to normative commitment. A closer look into it, there were two dimensions of workplace spirituality that were not significant predictors of normative commitment, the team's sense of community and sense of contribution to the community. Alignment between organizational and individual values was found to be the strongest predictors of auditors' normative commitment, followed by enjoyment at work, and opportunity for the inner life. The findings implied that employees who feel that there is alignment between organizational and their values would perceive higher normative commitment. Similarly, employees who felt that they experience enjoyment at their work and who felt that there is an opportunity for inner life would contribute to higher normative commitment. Moreover, this study found that there were two dimensions of workplace spirituality that were negatively and significantly related to continuance commitment. Besides, there were three dimensions of workplace spirituality that were not significant predictors of continuance commitment, alignment between organizational and individual values, sense of contribution to society, and opportunity for the inner life. Enjoyment at work was found to be the strongest predictor of auditors' continuance commitment, followed by the team's sense of community. The findings implied that employees who feel the enjoyment at work would perceive lower continuance commitment. Similarly, employees who perceived the team's sense of community would contribute to lower continuance commitment.

\section{The Relationship Between Workplace Spirituality and Perceived Organizational Support}

Figure 3 and Table 6 depicts the relationship between workplace spirituality and perceived organizational support through the research model with mediation. The current model displays $R^{2}$ value as 0.564 , suggesting that $56.4 \%$ of the variance in the extent of perceived organizational support can be explained by the five dimensions of workplace spirituality. $A$ close look shows that alignment with organizational values was positively related $(\beta=0.512$, $p<0.01)$ to perceived organizational support, and so was an opportunity for inner life $(\beta=0.310, p<0.01)$, and so was enjoyment at work $(\beta=0.115, p<0.05)$. On the other hand, the 
team's sense of community, and sense of contribution to the community were not significant predictors of perceived organizational support. As a result, the hypotheses of $\mathrm{H}_{2 b}, \mathrm{H}_{2 \mathrm{~d}}$, and $\mathrm{H}_{2 \mathrm{e}}$ were supported, whereas $\mathrm{H}_{2 \mathrm{a}}$ and $\mathrm{H}_{2 c}$ were not supported. Thus, overall the hypothesis $\mathrm{H}_{2}$ is partially supported.

Figure 3: Results Of The Path Analysis (With Mediator)

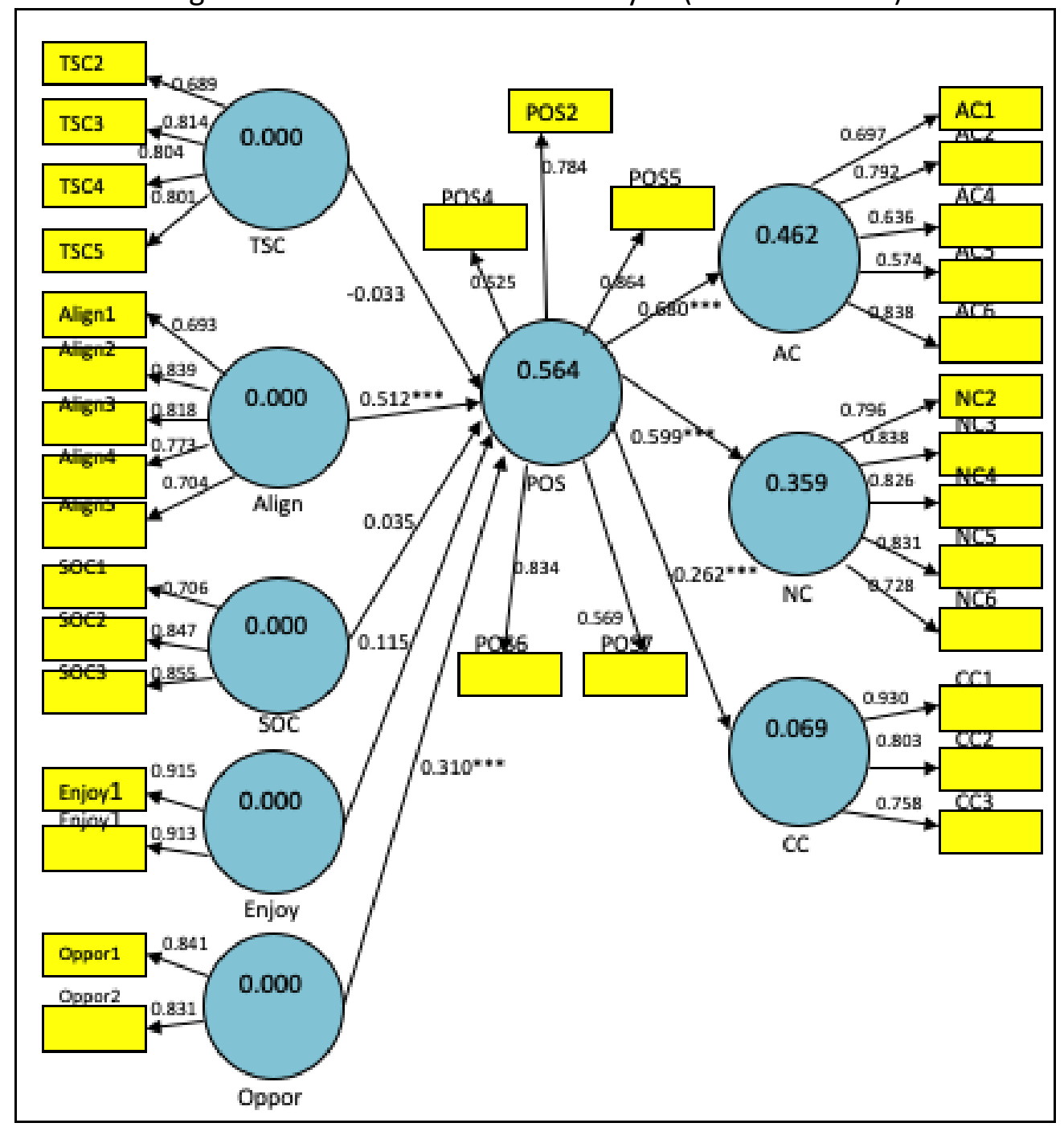


Table 6: Path Coefficients and Hypotheses Testing of Workplace Spirituality and POS (With Mediator)

\begin{tabular}{lllcc}
\hline Hypothesis & Relationship & Path Coefficient & $t$-value & Supported \\
\hline $\mathrm{H} 2 \mathrm{a}$ & TSC $\rightarrow$ POS & -0.033 & 0.448 & NO \\
$\mathrm{H} 2 \mathrm{~b}$ & Align $\rightarrow$ POS & $0.512^{* * *}$ & 6.558 & YES \\
$\mathrm{H} 2 \mathrm{c}$ & SOC $\rightarrow$ POS & 0.035 & 0.554 & NO \\
$\mathrm{H} 2 \mathrm{~d}$ & Enjoy $\rightarrow$ POS & 0.115 & 2.006 & YES \\
$\mathrm{H} 2 \mathrm{e}$ & Oppor $\rightarrow$ POS & $0.310^{* * *}$ & 4.586 & YES \\
\hline
\end{tabular}

$* * * p<.01$ at $t$-value $=2.58,{ }^{* *} p<.05$ at $t$-value $=1.96$

The second research question dealt with the relationship between employees' perceived workplace spirituality and employees' perceived organizational support. Hypothesis 2 posits that employees' perceived workplace spirituality will have a positive effect on perceived organizational support. This study found that two dimensions of workplace spirituality namely, alignment with organizational and individual values, and opportunity for inner life were significantly related to perceived organizational support. Alignment between an organization and individual values was found to be the strongest predictor of perceived organizational support, followed by an opportunity for the inner life. The findings implied that auditors who highly sense the organization's values are aligned with his/ her values would also highly perceive the organization has been supportive towards them. Similarly, auditors who sense the organization respect his/ her inner life would feel that the organization has been supportive towards them.

There was little research put together the workplace spirituality and perceived organizational support (Marschke, Preziosi \& Harrington, 2009; Moore \& Casper, 2006; Pawar, 2009). Perceived organizational support was added as a mediating variable as one of the contributions in this study. The study thus could not find much literature on this relationship. Alignment between an organization and individual values was found to be the strongest predictor of perceived organizational support. When auditors feel that the organization's values were the same as their values, this will contribute to a higher level of organizational support. If they find that the organizational values are not aligned with their values, this will let them feel that the organization is not so supportive towards them.

\section{The Relationship Between Perceived Organizational Support and Organizational Commitment}

Figure 3 and Table 7 depicts the relationship between the perceived organizational support and three dimensions of organizational commitment. The $\mathrm{R}^{2}$ value of 0.462 suggests that $46.2 \%$ of the variance in the extent of affective commitment can be explained by perceived organizational support. This study discovers that affective commitment was the highest among the three dependent variables. On the other hand, the $\mathrm{R}^{2}$ value of 0.359 proposes that $35.9 \%$ of the variance in the extent of normative commitment can be explained by the perceived organizational support. Continuance commitment was the lowest with the $\mathrm{R}^{2}$ value only 0.069 , suggesting that only $6.9 \%$ of continuance commitment can be explained by the perceived organizational support. A close $\mathrm{R}^{2}$ look shows that perceived organizational support was significantly related to three dimensions of organizational commitment, where the relationship between POS and affective commitment was positively significant at $(\beta=0.68$, $p<0.01)$. The relationship between perceived organizational support and normative 
commitment was also positively significant at $(\beta=0.599, p<0.01)$. However, the relationship between perceived organizational support and continuance commitment was negatively significant at $(\beta=-0.262, p<0.01)$. The hypotheses of $\mathrm{H}_{3 a}, \mathrm{H}_{3 b}$, and $\mathrm{H}_{3 c}$ were supported. Thus, the overall hypothesis $\mathrm{H}_{3}$ is supported.

Table 7: Path Coefficients and Hypotheses Testing of the Perceived Organizational Support and Organizational Commitment (With Mediator)

\begin{tabular}{lllll}
\hline Hypothesis & Relationship & Path Coefficient & $t$-value & Supported \\
\hline $\mathrm{H} 3 \mathrm{a}$ & POS $\rightarrow$ AC & $0.680^{* * *}$ & 15.795 & YES \\
$\mathrm{H} 3 \mathrm{~b}$ & POS $\rightarrow$ NC & $0.599^{* * *}$ & 12.281 & YES \\
$\mathrm{H} 3 \mathrm{C}$ & POS $\rightarrow$ CC & $-0.262^{* * *}$ & 3.548 & YES \\
\hline
\end{tabular}

$* * * p<.01$ at $t$-value $=2.58,{ }^{* *} p<.05$ at $t$-value $=1.96$

The third research question dealt with the relationship between employees' perceived organizational support and organizational commitment, namely affective commitment, normative commitment, and continuance commitment. Hypothesis 3 posits that employees' perceptions of workplace spirituality will have a positive effect on affective and normative commitment while hurting continuance commitment.

This study found that perceived organizational support was significantly and positively related to affective commitment and normative commitment. The result of this investigation implies that when employees perceived they have support from their organization, they are more likely to remain in the organization with affective and normative commitment. This result is similar to the previous studies (Lew, 2009; Meyer \& Allen, 1997). Besides, the study finding is also consistent with Organizational Support Theory and other social exchange approaches holding that employees reciprocate favorable treatment with greater commitment (Eisenberger et al., 1986; Meyer \& Allen, 1997; Shore \& Shore, 1995; Wayne, Shore, \& Liden, 1997). In a social exchange relation (Blau, 1964) support and treatment given by the employers (via the organizational support) will stimulate employees to reciprocate by having faith in the organization. The employers therefore should take efforts to value employee dedication that would help heighten employee performance.

This study had shown that perceived organizational support was significantly negatively predicting continuance commitment. Previous studies revealed that perceived organizational support decreases employees' feelings of continuance commitment, which develops when employees are forced to stay with an organization because of the high costs of leaving (Rhoades \& Eisenberger, 2002). Besides, employees with strong levels of continuance commitment are likely to feel that they "had to" remain with the organization because of the lack of attractive alternatives. One possible explanation is that perceived organizational support lessens the feelings of entrapment that develop when employees feel compelled to continue working for the organization because of the high costs associated with leaving (Aube, Rousseau, \& Morin, 2007; Rhoades and Eisenberger, 2002). A high level of perceived organizational support may help to restore the balance between the benefits awarded by the organization and the contributions of the individual. Indeed, when individuals perceive a high level of organizational support, the costs attached to quit their job will be perceived as being less significant than if they thought that they had given a great deal to the organization without having received anything in return. 


\section{The Mediation of Perceived Organizational Support}

To examine the mediating roles of the perceived organizational support in the organization as posited in hypotheses $\mathrm{H}_{4}\left(\mathrm{H}_{4 a}\right.$ to $\left.\mathrm{H}_{40}\right)$, the procedures as suggested by scholars (Kenny, 2003; Baron \& Kenny, 1986) were followed. Baron and Kenny (1986) establish a four-step criteria model to determine if mediation is present as the independent variable is significantly related to the dependent variable in the absence of the mediator, the independent variable is significantly related to the mediator, the mediator is significantly related to the dependent variables, and the effect of the independent variable on the dependent variable becomes insignificant upon the addition of the mediator into the equation. Table 8 presents how the $\mathrm{t}$-value is derived from. The analysis utilized the $\mathrm{t}$-value of the computation result of the mediation effect. Hence, the critical values used to determine the significant or nonsignificant effect was $+/-1.96$.

Table 8: Summary of the Indirect Impact of Perceived Organizational Support on the Relationship between Workplace Spirituality and Organizational Commitment

\begin{tabular}{|c|c|c|c|c|c|c|}
\hline $\begin{array}{l}\text { Hypo } \\
\text { thesis }\end{array}$ & Relationship & Path a & Path b & $\begin{array}{c}\text { Standard } \\
\text { Deviatio } \\
n \\
\text { (After } \\
\text { Bootstra } \\
\text { p) }\end{array}$ & $\begin{array}{c}\text { t-value } \\
\text { (After } \\
\text { Bootstra } \\
\text { p) }\end{array}$ & $\begin{array}{l}\text { Indirect } \\
\text { Impact }\end{array}$ \\
\hline $\mathrm{H} 4 \mathrm{a}$ & $\mathrm{TSC} \rightarrow \mathrm{POS} \rightarrow \mathrm{AC}$ & -0.033 & $0.680 * * *$ & 0.051 & -0.440 & NO \\
\hline $\mathrm{H} 4 \mathrm{~b}$ & $\begin{array}{l}\text { Align } \rightarrow \text { POS } \rightarrow \\
\text { AC }\end{array}$ & $0.512^{* * *}$ & $0.680 * * *$ & 0.058 & $6.003 * *$ & YES \\
\hline $\mathrm{H} 4 \mathrm{C}$ & $\mathrm{SOC} \rightarrow \mathrm{POS} \rightarrow \mathrm{AC}$ & 0.035 & $0.680 * * *$ & 0.045 & 0.529 & NO \\
\hline $\mathrm{H} 4 \mathrm{~d}$ & $\begin{array}{l}\text { Enjoy } \rightarrow \text { POS } \rightarrow \\
\text { AC }\end{array}$ & $0.115^{* *}$ & $0.680 * * *$ & 0.041 & 1.907 & NO \\
\hline $\mathrm{H} 4 \mathrm{e}$ & $\begin{array}{l}\text { Oppor } \rightarrow \text { POS } \rightarrow \\
\text { AC }\end{array}$ & $0.310 * * *$ & $0.680 * * *$ & 0.045 & $4.684^{* *}$ & YES \\
\hline$H 4 f$ & $\mathrm{TSC} \rightarrow \mathrm{POS} \rightarrow \mathrm{NC}$ & -0.033 & $0.599 * * *$ & 0.044 & -0.449 & NO \\
\hline $\mathrm{H} 4 \mathrm{~g}$ & $\begin{array}{l}\text { Align } \rightarrow \text { POS } \rightarrow \\
\text { NC }\end{array}$ & $0.512^{* * *}$ & $0.599 * * *$ & 0.049 & $6.259 * *$ & YES \\
\hline $\mathrm{H} 4 \mathrm{~h}$ & $\mathrm{SOC} \rightarrow \mathrm{POS} \rightarrow \mathrm{NC}$ & 0.035 & $0.599 * * *$ & 0.040 & 0.524 & NO \\
\hline $\mathrm{H} 4 \mathrm{i}$ & $\begin{array}{l}\text { Enjoy } \rightarrow \text { POS } \rightarrow \\
\text { NC }\end{array}$ & $0.115^{* *}$ & $0.599 * * *$ & 0.037 & 1.862 & NO \\
\hline $\mathrm{H} 4 \mathrm{j}$ & $\begin{array}{l}\text { Oppor } \rightarrow \text { POS } \rightarrow \\
\text { NC }\end{array}$ & $0.310 * * *$ & $0.599 * * *$ & 0.043 & $4.318^{* *}$ & YES \\
\hline $\mathrm{H} 4 \mathrm{k}$ & $\mathrm{TSC} \rightarrow \mathrm{POS} \rightarrow \mathrm{CC}$ & -0.033 & $0.262 * * *$ & -0.453 & 0.019 & NO \\
\hline $\mathrm{H} 4 \mathrm{I}$ & $\begin{array}{l}\text { Align } \rightarrow \text { POS } \rightarrow \\
\text { CC }\end{array}$ & $0.512 * * *$ & $0.262 * * *$ & 0.037 & $3.626 * *$ & YES \\
\hline $\mathrm{H} 4 \mathrm{~m}$ & $\mathrm{SOC} \rightarrow \mathrm{POS} \rightarrow \mathrm{CC}$ & 0.035 & $0.262 * * *$ & 0.019 & 0.482 & NO \\
\hline $\mathrm{H} 4 \mathrm{n}$ & $\begin{array}{l}\text { Enjoy } \rightarrow \text { POS } \rightarrow \\
\text { CC }\end{array}$ & $0.115^{* *}$ & $0.262 * * *$ & 0.021 & 1.435 & NO \\
\hline H4o & $\begin{array}{l}\text { Oppor } \rightarrow \text { POS } \rightarrow \\
\text { CC }\end{array}$ & $0.310 * * *$ & $0.262 * * *$ & 0.029 & $2.801 * *$ & YES \\
\hline
\end{tabular}

For path coefficient: ${ }^{* * *} p<.01$ at $t$-value $=2.58,{ }^{* *} p<.05$ at $t$-value $=1.96$

For $t$-value: ${ }^{* *} p<.05$ at $t$-value $=1.96$ 
The full or partial mediation was examined in the PLS path modeling through the path coefficient reduction between the independent and dependent variables. Table 9 presents the path coefficients without the mediator effect and with the mediator effect and also the result of partial or full mediation in one relationship.

Table 9: Summary of the Full or Partial Mediation of Perceived Organizational Support on the Relationship Between Workplace Spirituality and Organizational Commitment

\begin{tabular}{|c|c|c|c|c|c|}
\hline Hypothesis & Relationship & $\begin{array}{l}\text { Path } \\
\text { Coefficient } \\
\text { (Without } \\
\text { Mediation) }\end{array}$ & $\begin{array}{l}\text { Path } \\
\text { Coefficient } \\
\text { (With } \\
\text { Mediation) }\end{array}$ & $\begin{array}{l}\text { Indirect } \\
\text { Impact }\end{array}$ & $\begin{array}{l}\text { Partial/Full } \\
\text { Mediation }\end{array}$ \\
\hline $\mathrm{H} 4 \mathrm{a}$ & $\mathrm{TSC} \rightarrow \mathrm{POS} \rightarrow \mathrm{AC}$ & 0.083 & 0.088 & NO & No Mediation \\
\hline $\mathrm{H} 4 \mathrm{~b}$ & $\begin{array}{l}\text { Align } \rightarrow \text { POS } \rightarrow \\
\text { AC }\end{array}$ & $0.196^{* * *}$ & 0.006 & YES & Full Mediation \\
\hline $\mathrm{H} 4 \mathrm{C}$ & $\mathrm{SOC} \rightarrow \mathrm{POS} \rightarrow \mathrm{AC}$ & $0.170 * * *$ & $0.167 * * *$ & NO & No Mediation \\
\hline $\mathrm{H} 4 \mathrm{~d}$ & $\begin{array}{l}\text { Enjoy } \rightarrow \text { POS } \rightarrow \\
\text { AC }\end{array}$ & $0.294^{* * *}$ & $0.255^{* * *}$ & NO & No Mediation \\
\hline $\mathrm{H} 4 \mathrm{e}$ & $\begin{array}{l}\text { Oppor } \rightarrow \text { POS } \rightarrow \\
\text { AC }\end{array}$ & $0.309 * * *$ & $0.198 * * *$ & YES & $\begin{array}{l}\text { Partial } \\
\text { Mediation }\end{array}$ \\
\hline $\mathrm{H} 4 \mathrm{f}$ & $\mathrm{TSC} \rightarrow \mathrm{POS} \rightarrow \mathrm{NC}$ & 0.046 & 0.047 & NO & No Mediation \\
\hline $\mathrm{H} 4 \mathrm{~g}$ & $\begin{array}{l}\text { Align } \rightarrow \text { POS } \rightarrow \\
\text { NC }\end{array}$ & $0.372 * * *$ & $0.264^{* * *}$ & YES & $\begin{array}{l}\text { Partial } \\
\text { Mediation }\end{array}$ \\
\hline $\mathrm{H} 4 \mathrm{~h}$ & $\mathrm{SOC} \rightarrow \mathrm{POS} \rightarrow \mathrm{NC}$ & -0.038 & -0.046 & NO & No Mediation \\
\hline $\mathrm{H} 4 \mathrm{i}$ & $\begin{array}{l}\text { Enjoy } \rightarrow \text { POS } \rightarrow \\
\text { NC }\end{array}$ & $0.287^{* * *}$ & $0.269 * * *$ & NO & No Mediation \\
\hline $\mathrm{H} 4 \mathrm{j}$ & $\begin{array}{l}\text { Oppor } \rightarrow \text { POS } \rightarrow \\
\text { NC }\end{array}$ & $0.238 * * *$ & $0.173 * * *$ & YES & $\begin{array}{l}\text { Partial } \\
\text { Mediation }\end{array}$ \\
\hline H4k & $\mathrm{TSC} \rightarrow \mathrm{POS} \rightarrow \mathrm{CC}$ & $-0.275^{* * *}$ & $-0.271 * * *$ & NO & No Mediation \\
\hline $\mathrm{H} 4 \mathrm{I}$ & $\begin{array}{l}\text { Align } \rightarrow \text { POS } \rightarrow \\
\text { CC }\end{array}$ & 0.009 & 0.002 & YES & No Mediation \\
\hline $\mathrm{H} 4 \mathrm{~m}$ & $\mathrm{SOC} \rightarrow \mathrm{POS} \rightarrow \mathrm{CC}$ & 0.162 & 0.154 & NO & No Mediation \\
\hline $\mathrm{H} 4 \mathrm{n}$ & $\begin{array}{l}\text { Enjoy } \rightarrow \text { POS } \rightarrow \\
\text { CC }\end{array}$ & $-0.425 * * *$ & $-0.426 * * *$ & NO & No Mediation \\
\hline $\mathrm{H} 4 \mathrm{O}$ & $\begin{array}{l}\text { Oppor } \rightarrow \text { POS } \rightarrow \\
\text { CC }\end{array}$ & -0.062 & -0.074 & YES & No Mediation \\
\hline
\end{tabular}

For path coefficient: ${ }^{* * *} p<.01$ at $t$-value $=2.58,{ }^{* *} p<.05$ at $t$-value $=1.96$

The fourth research question deals with the mediating role of perceived organizational support on the relationship between workplace spirituality and organizational commitment. Hypothesis 4 posits that perceived organizational support mediates the relationship between workplace spirituality and organizational commitment. Based on the findings of this study, perceived organizational support fully mediated the relationship between employee's perceived alignment between organizational and individual values and affective commitment. This implies that employee's perceived alignment between organizational and individual values had an indirect impact on auditors' affective commitment. For auditors, if the organization's values are aligned with their values in life, it will indirectly influence the 
affective commitment to the firm. The values of the organization must be very prestigious and practical in the first place, then it will indirectly let auditors feel emotionally attach to the organization. Auditors are very independent and have logical thinking, if they feel that the organization is doing the right thing, they will follow them and feel happy to remain in the organization. A positive attitude on their works is the most important thing to an organization because they may work with their full heart and soul to increase the organization's performance.

Also, perceived organizational support partially mediates the relationship between employee's perceived opportunity for the inner life and affective commitment. Perceived organizational support also partially mediates the relationship between employee's perceived alignment between organizational and individual values and perceived opportunity for the inner life and normative commitment. This implies that employees' perceived opportunity for inner life had a direct and indirect influence on their affective commitment through perceived organizational support. Employee's perceived alignment between organizational and individual values, and perceived opportunity for inner life also had a direct and indirect impact on their normative commitment through perceived organizational support.

\section{Summary of Findings}

Table 10 presents the summary of the findings from the hypotheses testing.

Table 10: Summary of Hypotheses Testing

\begin{tabular}{|l|l|l|}
\hline \multicolumn{2}{|c|}{ Hypothesis } & \multicolumn{1}{|c|}{ Result } \\
\hline $\mathrm{H}_{1}:$ & $\begin{array}{l}\text { Workplace spirituality has a positive impact on organizational } \\
\text { commitment among auditors }\end{array}$ & $\begin{array}{l}\text { Partial } \\
\text { Supported }\end{array}$ \\
\hline $\mathrm{H}_{2}:$ & $\begin{array}{l}\text { Workplace spirituality has a positive impact on perceived } \\
\text { organizational support among auditors }\end{array}$ & $\begin{array}{l}\text { Partial } \\
\text { Supported }\end{array}$ \\
\hline $\mathrm{H}_{3}:$ & $\begin{array}{l}\text { Perceived organizational support has a positive impact on } \\
\text { organizational commitment among auditors }\end{array}$ & Supported \\
\hline $\mathrm{H}_{4}:$ & $\begin{array}{l}\text { Workplace spirituality has a positive impact on organizational } \\
\text { commitment with the mediation of perceived organizational } \\
\text { support among auditors }\end{array}$ & $\begin{array}{l}\text { Partial } \\
\text { mediation }\end{array}$ \\
\hline
\end{tabular}

\section{Discussions}

From the practical perspectives, the result of this study offers several suggestions to human resources managers and top management in public accounting firms in Malaysia. Specifically, human resources managers should use the results from this study to retain skilled auditors. Workplace spirituality about alignment between organizational and individual values and opportunity for inner life were found to have significant positive and direct effects on perceived organizational support. Perceived alignment between organizational and individual values had a significant indirect impact on auditors' affective commitment. Meanwhile, perceived opportunity for inner life had a direct and indirect impact on their affective commitment. Furthermore, perceived alignment between organizational and individual values, and perceived opportunity for inner life had a direct and indirect impact on their normative commitment. Given that spirituality would lead to higher affective and normative 
commitment, the results from this study would guide top management and managers on how to retain auditors' by revealing the workplace spirituality.

For those public accounting firms that are currently revealing spirituality in the workplace, the findings from this study suggest that these firms may want to continue to do so. Managers can further strive to enhance affective and normative commitment among auditors by continuing to let the auditors sense the opportunity for their inner life and let the auditors feel that their values and the organizational values are aligned. Therefore, auditors will become more productive over the long run compared with employees in firms where spirituality is ignored.

Also, managers need to be careful when preparing and carrying out organizational change because if changes impact spirituality in a negative way such as causing bleach in the individual-organizational alignment and harming the sense of opportunity for their inner life, then the outcome can be decreasing affective and normative commitment, as well as a subsequent decrease of individuals' efforts and performance and a drop in organizational performance.

Big four public accounting firm's authorities should also recognize that perceived organizational support has a direct effect on affective and normative commitment. The findings suggest that to retain employees with affective and normative commitment, the employee must perceive that they have organizational support from the organization. Therefore, public accounting firms must enhance organizational support through workplace spirituality such as perceived alignment between organizational and individual support and a sense of opportunity for an inner life that found to be significantly impact perceived organizational support. In this regard, top management of public accounting firms may want to implement more activities that can tie the auditor's heart by let them feel the organization's respect and make it important for the inner life. This could enhance perceived organizational support and increase affective and normative commitment.

\section{Contributions}

In contributions, the effect of workplace spirituality in predicting the auditors' organizational commitment should be of concern to both organization and society. From an organization's perspective, the auditors' turnover involved a tangible and an intangible cost. Failure to retain the auditors in an organization will affect the nation and society. It will cause a more serious "brain drain" issue. The result of this study indicates that the existence of spirituality in one organization will help the organization to retain its skilled auditors. The accounting firms therefore can focus on increasing workplace spirituality in their firms.

\section{Conclusion}

Malaysian accountants are flocking to other countries such as Singapore, China, Hong Kong, United Kingdom, and the Middle East particularly the Gulf Cooperation Council (GCC) nations (Tomlinson, Abdullah, \& Kolesnikov-Jessop, 2008). The migration of Malaysia's accountants abroad has intensified the staffing shortage in key areas like audit and assurance, and the financial industry. The panelists presenting at a forum organized by "Accountants Today" that was held in 2007 also claimed that the Malaysian accounting profession is suffering from "brain drain" and this issue needs to be addressed (Ravendran, 2008). 


\section{Acknowledgement}

The authors would like to say thank you the Universiti Sains Malaysia for the funding and research grant support. Ref. No: 1001/PJJAUH/8016077.

\section{References}

Allen, D. G., Shore, L. M., \& Griffeth, R. W. (2003). The role of perceived organizational support and supportive human resource practices in the turnover process. Journal of Management, 29(1), 99-118.

Allen, N. J., \& Meyer, J. P. (1996). Affective, continuance, and normative commitment to the organization: an examination of construct validity. Journal of Vocational Behavior, 49(3), 252-76.

Aranya, N., Kushnir, T., \& Valency, A. (1986). Organizational Commitment in a Male Dominated Profession. Human Relations, 86, 433- 448.

Aryee, S., Wyatt, T., \& Ma, K. M. (1991). Antecedents of Organizational Commitment and Turnover Intentions among Professional Accountants in Different Employment Settings in Singapore. The Journal of Social Psychology, 131(4), 545-556.

Ashmos, D. P., \& Duchon, D. (2000). Spirituality at work: a conceptualization and measure. Journal of Management Inquiry, 9(2), 134-45.

Aube, C., Rousseau, V., \& Morin, E. M. (2007). Perceived organizational support and organizational commitment: The moderating effect of locus of control and work autonomy. Journal of Managerial Psychology, 22(5), 479-495.

Bakshi, S., \& Krishna, S. (2009). Empirical Analysis of the Impact of Virtuality on Flexibility of Virtual Teams in Software Development Projects. AMCIS 2009 Proceedings.

Baron, R. M., \& Kenny D. A. (1986). Moderator-Mediator Variables Distinction in Social Psychological Research: Conceptual, Strategic, and Statistical Considerations. Journal of Personality and Social Psychology, 51(6), 1173-82.

Bennett, H., \& Durkin, M. (2000). The effects of organizational change on employee psychological attachment: an exploratory study. Journal of Managerial Psychology, 15(2), 126-47.

Blau, P. (1964). Exchange and Power in Social Life. New York: Wiley.

Chin, W. W. (2010). How to Write Up and report PLS Analyses in Handbook of Partial Least Squares, Vinzi, V. E., Chin, W.W., Henseler, J., and Wang, H. (eds.), Berlin: SpringerVerlag, pp. 655-690.

Clugston, M. (2000). The Mediating Effects of Multidimensional Commitment on Job Satisfaction and Intent to Leave. Journal of Organizational Behavior, 21, 477-486.

Cohen, A., \& Gatticker, U. E. (1994). Rewards and organizational commitment across structural characteristics: a meta-analysis. Journal of Business and Psychology, 9, 137157.

Efron, B., \& Tibshirani, R. (1993). An Introduction to the Bootstrap. Boca Raton, FL: Chapman \& Hall.

Eisenberger, R., Huntington, R., Hutchinson, S., \& Sowa, D. (1986). Perceived Organizational Support. Journal of Applied Psychology, 71, 500-507.

Gefen, D., Straub, D. W., \& Boudreau, M. C. (2000). Structural equation modeling and regression: Guidelines for research practice. (accessed November 23, 2011).

Giacalone, R. A., \& Jurkiewicz, C. L. (Eds) (2003). Handbook of Workplace Spirituality and Organizational Performance. M.E. Sharpe, New York, NY. 
Huang, J., Lin, Y., \& Chuang, S. (2007). Elucidating user behavior of mobile learning: A perspective of the extended technology acceptance model. The Electronic Library, 25(5), 586-599.

Hulland, J. S. (1999).Use of partial least squares (PLS) in strategic management research: A review of four recent studies. Strategic Management Journal, 20(4), 195-204.

Hutchison, S. (1997). A path model of perceived organizational support. Journal of Social Behavior and Personality, 12, 159-174.

Iverson, R. D., \& Buttigieg, D. M. (1999). Affective, normative, and continuance commitment: can the 'right kind' of commitment be managed? Journal of Management Studies, 36(3), 307.

Jaramillo, F., Mulki, J., \& Marshall, G. (2005). A meta-analysis of the relationship between organizational commitment and salesperson job performance: 25 years of research. Journal of Business Research, 58(6), 128-705.

Kenny, D. A. (2003), Mediation. http://www.users.rcn.com/dakenny/mediate.htm/.

Koch, J., \& Steers, R. (1978). Job attachment, satisfaction, and turnover among public employees. Journal of Vocational Behavior, 12, 119-128.

Krishnakumar, S., \& Neck, C. P. (2002). The 'what', 'why' and 'how' of spirituality in the workplace. Journal of Managerial Psychology 17(3), 153-164.

Lloyd, T. (1990). The nice company. Bloomsbury: London.

Marques, J., Dhiman, S., \& King, R. (2007). Spirituality in the Workplace: What it is, Why it matters, How to make it work for you. Riverside, CA: Personhood Press.

Marschke, E., Preziosi, R., \& Harrington, B (2009). Professional and Executives Support a Relationship between Organizational Commitment and Spirituality in the Workplace. Journal of Applied Business Research (JABR), Littleton, Colorado.

Masterson, S. S., Lewis, K., Goldman, B. M., \& Taylor, M. S. (2000). Integrating justice and social exchange: The differing effects of fair procedures and treatment on work relationships. Academy of Management Journal, 43(4), 738-748.

Meyer, J. P., \& Allen, N. J. (1984). Testing the side-bet theory of organizational commitment: Some methodological considerations. Journal of Applied Psychology, 69, 372-378.

Meyer, J. P., \& Allen, N.J. (1997). Commitment in the workplace: Theory, research, and application. Thousand Oaks, CA: Sage Publications.

Meyer, J. P., Stanley, D. J., Herscovitch, L., \& Topolnytsky, L. (2002). Affective, continuance and normative commitment to the organization: A meta-analysis of antecedents, correlates and consequences. Journal of Vocational Behavior, 62, 20-52.

Moore, T. W., \& Casper, W. J. (2006). An Examination of Proxy Measures of Workplace Spirituality: A Profile Model of Multidimensional Constructs. Journal of Leadership and Organizational Studies, 12(4), 109-118.

Mottaz, C. J. (1988). Determinants of organizational commitment. Human Relations, 41, 467482.

Mowday, R., Porter, L., \& Steers, R. (1982). Employee-organization linkages: The Psychology of commitment, absenteeism, and turnover. New York, Academic Press.

Nasurdin, A. M., Hemdi, M. A., \& Lye, P. G. (2008). Does Perceived Organizational Support Mediate the Relationship Between Human Resource Management Practices and Organizational Commitment? Asian Academy of Management Journal, 13(1), 15-36.

Oliver, N. (1990). Work rewards, work values and organizational commitment in an employeeowned firm: evidence from the UK. Human Relations, 43, 513-526. 
Park, S. M., \& Rainey, H. G. (2007). Antecedents, Mediators, and Consequences of Affective, Normative, and Continuance Commitment: Empirical Tests of Commitment Effects in Federal Agencies. Review of Public Personnel Administration, 27, 197-226.

Pawar, B. S. (2009). Workplace Spirituality Facilitation: A Comprehensive Model. Journal of Business Ethics, 90(3), 375-386.

Porter, L. W., Steers R. M., Mowday R. T., \& Boulian P. V. (1974). Organizational Commitment, Job Satisfaction, and Turnover among Psychiatric Technicians. Journal of Applied Psychology, 59, 603-609.

Ravendran, A. (2008). Brain drain or global mobility. Accountants Today January, 20-24.

Rego, A., \& Cunha, M. P. (2008). Workplace Spirituality and Organizational Commitment: An Empirical Study. Journal of Organizational Change Management, 21(1), 53-75.

Rhoades, L., \& Eisenberger, R. (2002). Perceived organizational support: A review of the literature. Journal of Applied Psychology, 87, 698-714.

Rhoades, L., Eisenberger, R., \& Armeli, S. (2001). Affective commitment to the organization: The contribution of perceived organizational support. Journal of Applied Psychology, 86, 825-836.

Schepers, J., Wetzels, M., \& de Ruyter, K. (2005). Leadership styles in technology acceptance: Do followers practice what leaders preach? Managing Service Quality, 15(6), 496-508.

Sekaran, U., \& Bougie, R. (2010). Research Methods for Business: A Skill Building Approach. UK: John Wiley \& Sons.

Shore, L. M., \& Shore, T. H. (1995). Perceived organizational support and organizational justice. In Cropanzano, R.S. \& K.M. Kacmar (Eds.). Organizational politics, justice, and support: Managing the social climate of the workplace, 149-164. Westport, CT: Quorum.

Suddaby, R., Gendron, Y., \& Lam, H. (2009). The organizational context of professionalism in accounting. Accounting, Organizations and Society, 34, 409-427.

Tayyab, S. (2006). Antecedents and Consequences of Organizational Commitment in Pakistan. Unpublished Ph.D. Thesis. Islamabad, Quaid-i-Azam University.

Thompson, C. M. (2000). The Congruent Life: Following the Inward Path to Fulfilling Work and Inspired Leadership. San Francisco: Jossey-Bass.

Tomlinson, P., Abdullah, N. A., \& Kolesnikov-Jessop, A. (2008). Dispatch (Asia version), Accounting and Business. Asia: ACCA.

Turner, J. (1999). Spirituality in the workplace. CA Magazine, 132(10), 41-42.

Wayne, S. J., Shore, L. M., \& Liden, R. C. (1997). Perceived organizational support and leadermember exchange: A social exchange perspective. Academy of Management Journal, 40, 82-111. 